\title{
Export Orientation in South Korea: How Helpful is Dependency Thinking to its Analysis?
}

Richard Luedde-Neurath

In spite of South Korea s transformation in two decades from one of the poorest nations in the world into one of the newly indust rialising countries. the dependency approach has tended to treat the case merely as an empirical confirmation of its analysis regarding the consequences of export orientation by Idcs / eg Fröbel 1978. Frank 1979. McCormack 1977. Sunoo 1978|.

The argument in this article is that such a view of the Korean experience is both questionable and unhelpful. It is questionable because of is frequent reliance on a) serious misrepresentations with respect to the nature of the strategy pursued. b) understatements of the progress made in Korea. coupled with exaggerations of the problems encountered. and c) a failure to acknowledge a number of developments pointing to a greater degree of Korean independence and bargaining strength. Meanwhile it is unhelpful because it misses some of the most interesting features of the experience. What is striking about Korea is not its conformity to any simple and often mechanistic versions of dependency-or for that matter of neoclassical thinking-but rather the particular way in which many of the pitfalls of export orientation. so usefully exposed by dependency analysis. were avoided. at least in part.

Given that data on many structural and qualitative aspects of the Korean experience are relatively scarce at present. no attempt can be made either to present a comprehensive evaluation of the strategy or to settle the debate in any way. It is hoped. however. that a case can be made for a careful reconsideration of the Korean experience and for more cautious applications to it of the dependency approach.

\section{Some Parameters of the Korean Case}

Korea. with its $37 \mathrm{mn}$ inhabitants. is extremely deficient in mineral. energy and land resources. Its population density - 374 persons per square $\mathrm{km}$ in 1978 - is one of the highest in the world. It has no significant raw materials other than some low grade coal and its agricultural production is constrained by the fact that only about 25 per cent of the land is flat enough for cultivation. In the discussion. therefore. it is important to recognise that certain types of dependence-such as that on trade and. more specifically. on processing for export so as to finance domestically consumed imports-are not caused by the strategy of export orientation. but are. within limits. independent of it.
Indeed. rather than blame such problems on the strategy it is more appropriate to explain the choice of strategy in terms of the implications for Korea of such resource deficiencies.

In spite of its resource problems. Korea displayed a number of internal characteristics by the early to mid 1960 s. when the strategy was embarked upon. which probably contributed substantially to its success but were independent of it. These included: the homogeneity of the nation: the experience of 'redistribution before growth as a result partly of the Civil War and partly of two far reaching land reforms: the efficient. literate and flexible nature of Korean labour. willingly or unwillingly tolerant of a strict social discipline: the emergence of viable local enterprises. organised along the lines of the Japanese Zaibatsu: and finally, the rise of a very powerful. highly centralised state | see Adelman and Robinson 1978|. What is particularly important and unusual about the latter is that this government's most important objective. apart from defence itself. was rapid economic development - essentially for the sake of national security against the North Korean threat.

In Koreas external environment there were also a number of factors which favoured the success of the strategy. Between 1953 and 1965 the vast volumes of grant aid given to Korea by the USA made it possible to reconstruct much of the economic infrastructure. to engage in wide-spread human resource investments and to satisfy basic consumption needs simultaneously | Hasan 1976: 216|. This aid. induced largely by the US commitment to the containment of communism in the area. also meant that Korea had virtually no foreign debt obligations in the early years of the strategy. The later latter half of the 1960 s was marked by Korea s exports to, contracts in and remittances from Vietnam. and more generally. by a rapid expansion of world trade |Frank et al 1975:231. Sano 1977: 45. Hassan 1976: 215). Whilst in the course of the 1970s. protectionism and resouce nationalism (to some extent counteracted by contracts in the Middle East) became increasingly problematic for Korea. the fact remains that the strategy was implemented in the context of parameters which were on the whole rather favourable to it.

\section{Central Features of the Strategy}

Had the Korean Government in this context embarked upon an export strategy involving the indiscriminate 
promotion of free trade and foreign investment. expecting market forces and transnational corporations (TNCs) to act as the vehicles for the country s economic development, then it might indeed have constituted a straightforward case for dependency thinking. But clearly that is not what occurred. The state. it appears, has been far more active as an initiating. implementing and controlling factor in the Korean economy than is commonly recognised / see Luedde-Neurath 1980. Kim and Rogier 1976, Kim 1974, Ashdown 1979. Kuznets and Sano 1977|.

This finds reflection in the powerful policy tools with which its economic objectives-as formalised in various five year plans and in specific industrial promotion laws - could be and were pursued. These included the government $s$ right directly to initiate industrial projects and to designate specific firms to take them up: strict financial control. which is likely to have been the single most important directive tool (by maintaining a tight control on all major financial institutions in Korea, it could influence not only the distribution but also the terms of credit - for favoured projects. real interest rates were of ten zero or even negative): the power to interfere directly with prices. profit margins. taxes and even the organisation of enterprises by way of selective measures directed at specific firms: and finally. trade controls. which in Korea did not merely comprise the commonly reported tariffs and selective quantitative restrictions. but were supplemented by certain highly effective direct measures. (Individuals or firms required a licence and registration to engage in foreign trade. in addition to which they of ten also required a specific licence for every transaction; the export-import link' system in turn could make permission to import conditional on a satisfactory export performance. Finally, special customs duties could be imposed so as to curb excess profits on imports.)

All this was apart from the incentive measures and fiscal and monetary policies often misleadingly presented as the only tools operating in Korea to promote the strategy. They were also accompanied by rather more objectionable policies which imposed a strict social discipline on the work force.

As regards the external factors. first the government controlled the level as well as utilisation of foreign loans by guaranteeing their repayment and by restricting private off-shore borrowing. This measure was particularly important. given that the vast majority of foreign investment in Korea took the form of loans rather than of direct investment. The government also ensured complementarity between local and foreign banks in Korea. This was done by stipulating that the main source of funds of the latter should be borrowing from their head office as opposed to local deposits, and that lending on the local market should proceed via 'swap. transactions with the Bank of Korea. As with domestic banks. there was interference with the terms and distribution of credit. Foreign direct investment was controlled by prior screening and the frequent imposition of export conditions as well as ownership share ratios. even before 1974. when a more explicit and formal distinction came to be made between eligible and ineligible types of direct investments | see Cohen 1975:721. It is primarily in free trade zones-which employed about 1 per cent of Korea's working population in 1975-that government interference has indeed been minimal. apart that is from the stipulation that all their production must be exported.

It should also be noted that foreign trading companies may not operate in Korea. that the country's stock market is off limits to foreigners and that Korea's patent act appears to entail a curious provision

dealing with the limits of patent rights which seems to suggest that infiringement of patents is permitted if the goods are to be exported

|Kim and Rogier 1976:470|.

though the precise implications of these factors have yet to be evaluated.

It is the combination of policy tools rather than any single one which has enabled the Korean Government to mobilise and direct, but also to monitor and control. both local and foreign factors in its economy. In practice. the government has played a more interventionist role in the 1970s than in the 1960s: it is hardly surprising that Korea has been described as

one of the free world's most tightly supentised economies, with the government initiating almost even major investment by the private sector and wielding enough power to ensure that companies which make such investments also make a profit IC. Smith. Financial Times supplement. 2 April 1979:IIII.

Naturally. noting the existence of such policy tools does not tell us exactly who benefited from their application; it might be large rather than small local firms. or foreign as opposed to local enterprises. Domestically. there is little doubt that a small number of large enterprise groups were the main beneficiaries rather than small firms. More relevant to the dependency debate is the fact that the Korean government has sought to promote national firms wherever possible and to assign a specific complementary role to external factors.

The evidence provided in this section is strongly at variance with versions of dependency thinking which 
view the role of Korea's policy towards foreign elements as unimportant, ineffective, or worst of all, as an 'instrument' of foreign capital |see Frank 1979:24|. Without wishing to dispute the repressive nature of the regime and the high profits earned by those foreign interests which were admitted leg Sunoo 1978:324 | we would suggest that, both directly via the selection and control of foreign interests and indirectly via the promotion of local enterprises, such policy favourably affected the terms of Korea's integration into the world economy and, further, that it served at least partly to avoid some of the pitfalls that a more naïve approach to export orientation may well have entailed. However, many dependency analysts have yet to accept this view. And it is only when Korea's path is accepted as a clear deviation from the type of strategy criticised by dependency thinking that far more interesting issues-about how the implementation and maintenance of such a policy was possible, for example, or about the extent and limits of the Korean deviations - can be considered.

\section{Some Results of the Strategy}

Evaluations of policy achievements are much influenced by the particular standards applied. Dependency thinking has contributed in many ways to the demystification of traditional yardsticks of development success. but the impression is of ten unavoidable that the criteria by which it assesses cases such as Korea are themselves somewhat utopian. The achievements of the country must always be assessed against the background of its resource deficiencies and, more importantly, against the tremendous problems facing the Third World in general.

While we do not wish to suggest that Korea achieved the best possible results, we hope to show in this section that certain widespread 'dependency objections' to export orientation - that it fails to generate employment, does not improve real wages and worsens income distribution. can be challenged in the Korean case. while arguably the assertions made about 'chronic' balance of payments crises and debt problems have been exaggerated. What we will not dispute is that enormous social costs were incurred in the course of the strategy.

Korea's success according to orthodox criteria, such as nominal or per capita GNP growth. export expansion or structural transformation in production and exports in the direction of manufacturing and particularly towards the heavy and chemical industries, is commonly reported and can be taken as beyond dispute, so that the relevant data will not be reproduced here.

The employed population in Korea increased from $7.7 \mathrm{mn}$ in 196.3 to $13.5 \mathrm{mn}$ in 1978 , with unemployment - at least according to the rather optimistic official figures - falling from 8 per cent to 3 per cent during this period. In manufacturing. employment expanded at 13 per cent a year between 1963 and 1977, which makes Korea one of the few ldcs where the actual growth of manufacturing employment has even approximately kept pace with the requirements (namely 14 per cent) imposed by the mere expansion of the labour force. As a result, objections to the Korean experience on account of its failure to generate employment are not convincing.

Official figures suggest a substantial rise in real incomes. The index of real farm household income rose by 208 per cent between 1962 and 1978. The corresponding index for salary and wage-earner households (all cities) rose by 122 per cent in the same period, while that for manufacturing real wages increased by 165 per cent between 1968 and 1978. Absolute wages remain extremely low by international standards, in spite of such improvements.

Finally, there can be little doubt that a substantial deterioration in income distribution has occurred. at least during the 1970s | see Choo and Kim 1978|. In spite of this however. Korea's income distribution remains relatively equal by ldc standards, so that attacks on the experience from this angle are questionable.

Dependency analysts are correct, however, when they argue that if criteria such as absolute wage levels. inflation, working day length, unemployment or medical benefits, housing, pollution, safety precautions at work or labour laws are considered, the experience is revealed at its least impressive | see Ashdown 1979, Suh 1979|. The social costs of the Korean model are not disputed here, nor in our view can they be justified. Unfortunately. however, very few ldes can stand scrutiny according to these rather fundamental criteria.

Korea has traditionally experienced a deficit in both its visible trade and its payments accounts. But whereas in 1962 imports were eight times as large as exports, by 1978 imports were only 20 per cent larger than exports. While the latter grew on average at 40 per cent annually between 1970 and 1978. imports grew at only 26 per cent in value terms during this period. Thus on the whole the trend up to 1978 was towards a closing trade gap. The overall balance of payments situation has been mixed, but in some years, such as in 1977. highly encouraging. Especially in recent years it has been aided by invisible income, notably from construction activities in the Middle East (the earnings from which amounted to about USS2bn in 1978), so that the 'chronic' problem did not materialise. 
As far as external debt is concerned, the absolute levels of Korean debt (outstanding, disbursed) have increased rapidly from about US\$1.8bn in 1970 to just below US\$1 I bn in 1978. Significantly, however, Korea is one of the few newly industrialising countries where the debt service as a percentage of exports of goods and services fell between 1970 and 1977, namely from 19 to 9 per cent. Hence, even though foreign debt always constitutes a potential problem, if exports should become constrained or uncompetitive in future, it has not represented a chronic problem to date. Ironically, Korea's debt may turn out to constitute a weapon against developed country (especially US) protectionism. given that arguably it would be this protectionism rather than lack of Korean export competitiveness which would be at the root of any default on its debt.

Summing up this section, it appears that the benefits to Korea from the strategy of export orientation have been understated by dependency analysis while the problems have been exaggerated. That is not to deny, however, that, according to many important criteria. the experience is open to severe criticism. especially in relation to its social costs. It should also be noted that the 1978-79 period has been marked by a reversal of the trends described, though so far at least Korea's ability to deal with economic crises has been remarkable and has continuously defied dependency expectations.

\section{Trends in Korean Dependence}

In an absolute sense Korea has clearly increased its dependence on the international system over the last two decades. On the one hand, resource deficiencies inevitably made the country more dependent on external resources and markets as its economy expanded. On the other hand, Korea's ambitious programme to develop the capital, skill and technology intensive heavy and chemical industries meant that its demands on the international system shifted fundamentally towards areas which are by their very nature more inaccessible. It is important to recognise, however, that these are symptons of success, not failure.

An area in which Korea has become more independent is its financing of trade. Whereas in 1962 Korean foreign exchange financed 42 per cent of the country's imports, by 1978 this figure had risen to 82 per cent. Furthermore, the purchasing power of Korean exports has increased remarkably rapidly. In spite of adverse movements in its net barter terms of trade $(1975=100)$ after 1968-falling from 150 in that year to their lowest level in 1975 , but rising again to 128 by 1978 - the purchasing power index of Korean exports $(1970=100)$ stood at 31 for 1966 , at 281 for 1975 ; but then, during the $1976 / 77 / 78$ period, rose to 436,555 and 665 respectively.

These highly favourable developments, however, should not distract from the potentially vulnerable nature of Korean trade in other respects. First, a rather high 40 per cent of Korea's GNP is attributable to the export of goods and services. Secondly, Korea's exports have a high import component, given that between 1966 and 1977 the direct import content of its total commodity exports was in the order of 40 per cent / see Hong 1978:39|. And, thirdly, Korean trade is highly concentrated geographically. In spite of certain diversifications since the mid 1960s, mainly toward Europe and the Middle East, over 50 per cent of Korea's trade is still with Japan and the USA. The former is the country's main import supplier, while the latter is its main market. And whereas Korea has gradually transformed its trade deficit with most parts of the world into a trade surplus, the deficit with Japan has generally increased and in 1978 was nearly US\$1.0bn higher than Korea's overall trade deficit for that year of US\$2.3bn | see Luedde-Neurath 1980|.

On each of these levels, problems may arise or, indeed, be imminent. To the extent that the nature of Korea's structural integration into the global system is such as to prevent the adjustments that may be necessary to cope with such problems - for example, reorientation of production, increases in domestic value added or a more balanced geographical distribution of trade-its dependence on that system may indeed turn out to be problematic. It is not at all clear, however, that Korea will be unable to adapt to the new realities of the world economy, and hence the questions arising from the vulnerabilities outlined should not be prejudged at this stage.

Korea's gross fixed capital formation as a percentage of GNP has risen from 14 per cent in 1962 to an impressive 31 per cent in 1978. In view of this, it is particularly significant that Korea's dependence on foreign savings to finance such investments has fallen from 83 per cent in 1962 to just over 10 per cent in 1978.

While foreign investment played a crucial role in Korea's development strategy. most of this investment, namely 94 per cent of the cumulative total between 1959 and 1978, took the form of loans as opposed to direct investment. Much of the direct investment 165 per cent by 1974) took the form of joint ventures. The cumulative total direct investment by 1978 was US $\$ 873 \mathrm{mn}$, of which over one third was made in 1973-74 alone and more than another third in the 1976-78 period. 
If we accept that loans are less problematic than direct investment. and joint ventures are preferable to wholly owned subsidiaries from the point of view of potential foreign control. it follows that Korea pursued a relatively wise approach to foreign investment thereby probably avoiding some of the pitfalls that a great reliance on direct investment may have entailed.

In essence. however. the issue of external control is not resolved by pointing to the predominance of loans and joint ventures in Korea. simply because foreign domination can take many and rather subtle forms. such as sub-contracting or technology licensing for example. The difficulties arising from this cannot be resolved here. Instead. four reasons will be suggested why Korea may be acquiring a greater degree of independence in the world system.

First. Korean indigenous firms are developing rapidly by international standards. Among Fortune $s$ list of the top 500 non-US corporations. ranked according to sales. nine Korean firms were present in 1977. compared to three in 1976. The largest of these. a manufacturing firm. improved its rank from 278th in 1976 to 78 th in 1978. with sales of US\$3.7bn. If we focus on the top performances in terms of changes in sales or profits. Korean firms are even among the top ten. In 1977 the top three places. and in 1978 the third place. in terms of increases in sales. were occupied by Korean firms. In the corresponding category for increases in profits both in 1977 and 1978. one Korean firm can be found.

Secondly. Korea is itself beginning to go transnational. By June 1979. the cumulative total foreign investment on the part of Korea was US\$134mn. involving 367 projects. Much of this investment. namely 31 per cent. occurred in the first half of 1979 alone.

Thirdly. Korea is developing its own channels of marketing and to a lesser extent input procurement. Korea 's trading companies. inspired by their Japanese counterparts and linked to the large business conglomerates of Korea. have been succesful in gaining control of the country's exports since their establishment in 1974. In 1975 they accounted for 5 per cent of such exports. by 1978 for 32 per cent and in 1979 the provisional figure was 36 per cent. Owing in part to their enormous economies of scale. these companies can distribute even small volumes of exports to a large number of countries. Not unrelated is the fact that in 1978 Korean flag vessels transported no less than 46 per cent of the country's trade volume. It should be noted. however. that Korean trading companies do not as yet figure importantly on the import side. accounting for only 4 per cent of the Korean total in 1978. This may to some extent negate the benefits of marketing and export control. Korea is attempting increasingly. however. to come to more direct arrangements with its raw material suppliers.

Finally. the fourth reason for Korea s greater relative independence is its increasing sophistication in the procurement and absorption of technology. In many areas it is clear that technology procurement deprives Korea of a high share of its value added. The cumulative total royalty payments by Korea between 1962 and 1978 amount to US $\$ 230 \mathrm{mn}$. while the figure for technical service contracts amounts to US\$37mn (1972-78). In spite of this. however. some as yet rather subtle signs of improvement are visible.

Currently the country is embarking on a major programme to expand local research and development activities. Technology licencing is being increasingly preferred to joint venture arrangements. and Koreans are vigorously attempting to resist foreign 'turnkey" bidders for domestic construction contracts. in some cases even 'packaging' such contracts so that foreign firms must train Koreans in specific skills during their activity in Korea. In shipbuilding and vehicle manufacture a diversification within the developed world of technical assistance procurement is visible. and skilled individuals from advanced nations are being engaged in Korea so as to diffuse the technology embodied in them. For example. Koreans have designed their own colour television set by luring some Japanese engineers to Korea.

Korea s capacity to absorb technology is also growing. Symptomatic of this is the increasing Japanese reluctance to supply advanced technology to Korea. even when in other countries such companies are searching for customers. This occurred. for example in the case of video-tape technology. Another example is the adaptation of an American ground-to-air missile for ground-to-ground use by adding Korean solid state technology.

While the developments identified in this section with respect to Korean trade. investment. local capital. overseas investment. foreign trade networks and technology may to some extent be counteracted by other factors. or may be in their early stages. they must nevertheless be taken into account by any serious analysis of the Korean experience. What is more. they are likely to constitute developments which provide Korea with a greater degree of independence within the international system. in spite of its incresing absolute dependence on the latter.

Dependency thinking on Korea to date. however. generally fails to acknowledge the existence. let alone the importance. of such movements. which have taken place in spite of export orientation. And in ignoring 
factors which modify its own predictions or even negate them. it has tended to miss precisely those aspects of the Korean experience which make the case particularly interesting.

\section{Conclusion}

Perhaps the central conclusion of this article is that the manner in which dependency thinking has so far been applied to the Korean experience has not been particularly helpful to its understanding. If anything. it has posed obstacles to the analysis of the most interesting features of the case.

The irrelevance of the type of dependency thinking applied to the Korean case so far can be traced primarily to its rigid perceptions and mechanistic predictions with respect to the nature and outcome of the interaction between Korea internal factors and their external environment. All too often, it seems. theoretical preconceptions have taken precedence over the careful analysis of the actual experience and the policies at its root.

In a modified form. on the other hand, dependency thinking can be extremely useful. indeed indispensable for the analysis of cases such as Korea. when it is perceived as a body of theories which expose potentially problematic types of interaction between internal and external factors of Idcs. as well as possible adverse implications for their development.

Seen in this way. dependency thinking constitutes the basis for an investigation of the extent to which such problems have materialised, been modified or even avoided in practice. In our view. it is this approach which is likely to yield the most interesting questions for investigation in the Korean case and which may in turn throw a new light on the very nature of dependency. or-what is most important for ldes-on how it might be counteracted.

note: the more general dependency references are not given here but in the bibliography at the end of this Bulletin.

\section{References}

Adelman. I. and S. Robinson. 1978. Income Distribution Policy in Developing Countries: a Case Study of Korea. published for the World Bank. Oxford University Press

Ashdown. J.. 1979. 'South Korea: the entrepreneurial state' Economic and Political Weekly. March
Choo. H. and K. Daemo, 1978. Probable Size Distribution of Income in Korea: Over Time and by Sectors. Korea Development Institute

Cohen. B. I.. 1975, Multinational Firms and Asian Exports. Yale University Press

Economic Planning Board. 1979. Major Statistics of Korean Economy 1979. Seoul. Korea

Frank. C. R. Jr.. et al. 1975. 'Foreign trade regimes and economic development: Korea:. National Bureau of Economic Research. vol VII. New York

Hasan. P.. 1976, Korea: Problems and Issues in a Rapidly Growing Economy. a World Banking Country Economic Report. Hopkins University Press. Baltimore and London

Hasan, P. and D. C. Rao. 1979. Korea: Policy Issues for LongTerm Development, published for the World Bank. Johns Hopkins University Press

Hong. W.. 1978. 'Export plan and actual export performance in Korea'. Economic Review: vol XII no 1. December. Seoul National University

Kim. C. and R. H. Rogier. 1976. 'International trade and investment law in the Republic of Korea. Journal of World Trade Law. vol 10 no 5. September/October

Kim. K.. 1976. 'Political factors in the formation of the entrepreneurial elite in South Korea. Asian Survey. vol XVI no 5. May

Kuznets. P. W.. 1977. Economic Growth and Structure in the Republic of Korea. Yale University Press. New Haven and London

Luedde-Neurath. R.. 1980. 'Korea: its present and future impact on the UK and EEC' in A. R. Riddell (ed). Adjustment or Protectionism: the Challenge to Britain or Third World Industrialisation. Catholic Institute for International Relations. London

McCormack, G.. 1977. 'South Korean economy: GNP versus the people' in G. McCormack and J. Gittings (eds). Crisis in Korea. Spokesman Books. Nottingham

Office of Planning and Coordination. Office of the Prime Minister. Republic of Korea. Evaluation Report of the Second Year Programme: Fourth Five Year Economic Development Plan. Seoul

Sano. J. R.. 1977. 'Foreign capital and investment in South Korean Development". Asian Economies. no 23. December

Suh. S. H.. 1979. 'The patterns of poverty in Korea'. Working Paper 7903. Korea Development Institute

Sunoo, H. H.. 1978. 'Economic development and foreign control in South Korea. Journal of Contemporary Asia. vol 8 no 3

Tokyo Financial Revien: vol 4 no 11. 'The Korean economy in transition: November 1979

Watanabe, T.. 1978. 'Heavy and chemical industrialisation and economic development in the Republic of Korea'. The Developing Economies. vol XVI no 4. December 